\title{
Pengaruh Pemberian Jus Tomat Terhadap Perubahan Tekanan Darah Pada Usia 35-45 Tahun Di Desa Kempo Kecamatan Kempo Kabupaten Dompu Tahun 2019
}

\author{
Uswatun Hasanah', Junaidin², Zulkarnain ${ }^{3}$ \\ STIKES YAHYA BIMA \\ Email : uswatunhasanah280198@gmail.com
}

\begin{abstract}
ABSTRAK : Penyakit hipertensi merupakan masalah kesehatan yang mengakibatkan penyakit jantung dan stroke otak. Salah satu terapi yang digunakan untuk menurunkan tekanan darah adalah terapi tomat karena kaya akan likopein, kalium, dan bioflavonoid. Tujuan dari penelitian ini adalah untuk mengetahui Pengaruh Pemberian Jus Tomat Terhadap Perubahan Tekanan Darah Pada Usia 35-45 Tahun Di Desa Kempo Kecamatan Kempo Kabupaten Dompu Tahun 2019. Penelitian ini menggunakan One Group Pre Test-Post Test Design. Populasi penelitian ini sejumlah 44 penderita. Teknik pengambilan sampel dengan teknik Purposive Sampling sebanyak 32 orang dan menggunakan Uji Wilcoxon Signed Rank Test. Instrumen dalam penelitian ini menggunakan spigmomanometer jarum, stetoskop, dan lembar observasi. Hasil analisa jus tomat diperoleh nilai sig $\rho \mathrm{V}$ hari Pertama $=0,014<\alpha 0,05$, artinya ada pengaruh pemberian terapi jus tomat terhadap perubahan tekanan darah pada penderita hipertensi. Hasil analisa jus tomat diperoleh nilai sig $\rho \mathrm{V}$ hari Kedua $=0,000<\alpha 0,05$, artinya ada pengaruh pemberian terapi jus tomat terhadap perubahan tekanan darah pada penderita hipertensi. Hasil analisa jus tomat diperoleh nilai sig $\rho \mathrm{V}$ hari Ketiga $=$ $0,003<\alpha \quad 0,05$, artinya ada pengaruh pemberian terapi jus tomat terhadap perubahan tekanan darah pada penderita hipertensi. Dan hasil analisa jus tomat diperoleh nilai sig $\rho \mathrm{V}$ hari Keempat $=0,000<\alpha$ 0,05, artinya ada pengaruh pemberian jus tomat terhadap perubahan tekanan darah pada usia 35-45 tahun di Desa Kempo Kecamatan Kempo Kabupaten Dompu Tahun 2019. Kesimpulan dalam penelitian ini ada signifikasi perubahan tekanan darah sebelum dan sesudah pemberian jus tomat pada penderita hipertensi pada usia 35-45 tahun di Desa Kempo Kecamatan Kempo Kabupaten Dompu tahun 2019.
\end{abstract}

Kata kunci : Tekanan Darah, Jus Tomat, Penderita Hipertensi.

\section{PENDAHULUAN}

Menurut American Heart Association di Amerika, Tekanan darah tinggi ditemukan satu dari setiap tiga orang atau 65 juta orang dan $28 \%$ atau 59 juta orang mengidap prehipertensi. Semua orang yang mengidap hipertensi hanya satu pertiganya yang mengetahui keadaanya dan hanya $61 \%$ medikasi. Sampai saat ini, hipertensi masih merupakan tantangan besar di Indonesia. Hipertensi merupakan kondisi yang sering ditemukan pada pelayanan kesehatan primer.

Data WHO 2015 menunjukkan sekitar 1,13 miliar orang di dunia menderita hipertensi. Artinya, 1 dari 3 orang di dunia terdiagnosis menderita hipertensi, hanya $36,8 \%$ di antaranya yang minum obat. Jumlah penderita hipertensi di dunia terus meningkat setiap tahunnya, diperkirakan pada 2025 akan ada 1,5 miliar orang yang terkena hipertensi. Diperkirakan juga setiap tahun ada 9,4 juta orang meninggal akibat hipertensi dan komplikasi.

Menurut Riskesdas tahun 2018, prevalensi hipertensi di Indonesia masih tinggi. Terjadi peningkatan dari $32,4 \%$ pada tahun 2016 menjadi 34,1\% pada tahun 2018 . Hipertensi berada pada urutan pertama dari sepuluh diagnosa penyakit tidak menular terbanyak tahun 2018.

Berdasarkan data Dinas Kesehatan Provinsi NTB hipertensi berada pada urutan ke tiga dari sepuluh penyakit terbanyak di Puskesmas di Provinsi NTB tahun 2016. Berdasarkan data Dinas Kesehatan Provinsi NTB tahun 2017 prevalensi tertinggi di Kabupaten Bima
(69.64\%), diikuti Kota Bima (62,71\%), Kabupaten Dompu (50,02\%), Lombok Timur (33,83\%), Sumbawa $(28,66 \%)$, Sumbawa Barat $(27,39 \%)$, Lombok Tengah $(11,53 \%)$, Kota Mataram (7,15\%), Lombok Barat dan Lombok Utara.

Hipertensi merupakan penyakit multifaktorial yang timbul karena interaksi antara faktor risiko tertentu, yaitu riwayat keluarga hipertensi, usia, jenis kelamin, alkohol, konsumsi garam berlebihan, obesitas, merokok dan aktivitas fisik yang kurang. Hipertensi dapat terjadi pada segala usia, namun sering dijumpai pada orang yang berusia 35 tahun atau lebih [1].

Berdasarkan data yang di dapatkan di Puskesmas Kempo pada tanggal 12 April 2019, selama tahun 2018 terdapat 1.016 pasien penderita hipertensi yang berasal dari Desa Kempo, Ta'a, Dorokobo, Soro, Konte, Tolokalo, Songgajah dan Soro Barat. Penelitian dilakukan di Desa Kempo, Kecamatan Kempo, Kabupaten Dompu karena memiliki jumlah pasien hipertensi terbanyak sejumlah 205 pasien.

\section{METODE PENELITIAN}

Penelitian ini menggunakan jenis penelitian kuantitatif dengan menggunakan Quasy Experimental Design atau desain eksperimen semu dan metode one group pre test-post test design. Penelitian dilakukan di Desa Kempo Kecamatan Kempo Kabupaten Dompu. Waktu penelitian ini dilaksanakan mulai dari tanggal 29 
Juli-10 Agustus 2019. Sampel merupakan bagian dari populasi yang dipilih menjadi obyek penelitian. Sampel penelitian ini menggunakan purposive sampling sebanyak 32 responden yang memenuhi kriteria inklusi-eksklusi. Kriteria inklusi: Penderita hipertensi yang berusia 35-45 tahun, Mengidap Penyakit hipertensi essensial, Tidak menderita penyakit sistemil lanjut (Jantung dan Diabetes), mengkonsumsi obat antihipertensi Tidak mengkonsumsi buah lainnya pada saat dilakukan intervensi, Tidak sedang mengkonsumsi obat antihipertensi selama dilakukan penelitian dan bersedia menjadi responden. Kriteria eksklusi: Penderita hipertensi yang berusia $<35$ dan $>45$ tahun, Penderita Hipertensi Sekunder, Mengidap penyakit sistemik lanjut (Jantung dan Diabetes), Mengkonsumsi buah lainnya pada saat dilakukan intervensi, Sedang dan Tidak bersedia menjadi responden. Dalam penelitian ini responden diberikan jus buah tomat yang terbuat dari 150 gr buah tomat matang dihaluskan dengan blender tanpa tambahan air dan gula diberikan selama 4 hari. Tekanan darah diukur dengan Tensimeter dan stetoskop [2].

\section{HASIL DAN PEMBAHASAN}

\section{Karakteristik Umum responden}

Jumlah responden dalam penelitian ini berjumlah 32 orang masyarakat yang mengalami hipertensi yang berusia 35-45 tahun di Desa Kempo tahun 2019. Karakteristik responden berdasarkan usia, jenis kelamin dan tingkat pendidikan.

Tabel 1. Karakteristik responden berdasarkan usia, jenis kelamin dan tingkat pendidikan

\begin{tabular}{|l|l|l|}
\hline $\begin{array}{l}\text { Karekter } \\
\text { Responnden }\end{array}$ & Frequesi (n) & Persen (\%) \\
\hline Usia & \\
\hline $35-40$ Tahun & 26 & 81,2 \\
\hline $41-45$ Tahun & 6 & 18,8 \\
\hline Jumlah & $\mathbf{3 2}$ & $\mathbf{1 0 0}$ \\
\hline Jenis Kelamin & 7 & 21,9 \\
\hline Laki-laki & 7 & 78,1 \\
\hline Perempuan & 25 & $\mathbf{1 0 0}$ \\
\hline Jumlah & $\mathbf{3 2}$ \\
\hline Tingkat Pendidikan & 21,9 \\
\hline SD & 7 & 31,2 \\
\hline SMP & 10 & 37,5 \\
\hline SMA & 12 & 9,4 \\
\hline S1 & 3 & $\mathbf{1 0 0}$ \\
\hline Jumlah & $\mathbf{3 2}$ \\
\hline
\end{tabular}

Berdasarkan tabel 1 menjelaskan bahwa karakteristik responden berdasarkan usia 35-40 tahun di desa Kempo diperoleh yang mengalami hipertensi sebanyak 26 responden $(81 \%)$ dan usia 41-45 tahun sebanyak 6 responden (19\%) sedangkan berdasarkan Jenis Kelamin di desa Kempo diperoleh yaitu laki-laki sebanyak 7 orang (22\%) dan perempuan sebanyak 25 orang $(78 \%)$ dan berdasarkan Tingkat Pendidikan yaitu yang paling banyak adalah responden yang berpendidikan SMA yang berjumlah 12 orang (38\%) dan paling sedikit yaitu responden yang berpendidikan S1 berjumlah 3 orang (9\%).

2. Analisa Data

Analisa Hasil Pre Post Intervensi Pemberia Jus Tomat

Tabel 2. Hasil pre post intervensi pemberian jus tomat Hari Pertama

\begin{tabular}{|c|c|c|c|c|c|c|c|c|c|}
\hline \multirow{2}{*}{ Perlakuan } & \multicolumn{10}{|c|}{ Hipertensi } \\
\cline { 2 - 10 } & \multicolumn{2}{|c|}{ TD Ringan } & \multicolumn{2}{|c|}{$\begin{array}{c}\text { TD } \\
\text { Sedang }\end{array}$} & \multicolumn{2}{|c|}{$\begin{array}{c}\text { TD } \\
\text { Berat }\end{array}$} & Rerata & $\mathrm{n}$ & $\%$ \\
\hline Pree tes & 11 & $\begin{array}{c}34,4 \\
\%\end{array}$ & 7 & $\begin{array}{c}21,9 \\
\%\end{array}$ & 14 & $\begin{array}{c}43,8 \\
\%\end{array}$ & 3,09 & 32 & 100 \\
\hline Post tes & 12 & $\begin{array}{c}37,5 \\
\%\end{array}$ & 11 & $\begin{array}{c}34,4 \\
\%\end{array}$ & 9 & $\begin{array}{c}28,1 \\
\%\end{array}$ & 2,91 & 32 & 100 \\
\hline Jumlah & 23 & $\begin{array}{c}71,9 \\
\%\end{array}$ & 18 & $\begin{array}{c}56 \\
\%\end{array}$ & 23 & $\begin{array}{c}71,9 \\
\%\end{array}$ & $6 \%$ & 64 & 200 \\
\hline
\end{tabular}

Berdasarkan Tabel 2 Hari Ke-1 Sebelum perlakuan menunjukan yang paling banyak yaitu responden yang Hipertensi Berat sebanyak 14 orang $(43,8)$ dan paling sedikit yaitu Hipertensi Sedang sebanyak 7 orang $(21,9 \%)$. Setelah perlakuan menunjukan yang paling banyak yaitu responden yang Hipertensi ringan sebanyak 12 orang $(37,5 \%)$ dan paling sedikit yaitu Hipertensi Berat sebanyak 9 orang (28.1\%).

Tabel 3. Hasil pre post intervensi pemberian jus tomat Hari Kedua

\begin{tabular}{|c|c|c|c|c|c|c|c|c|c|}
\hline \multirow{2}{*}{ Perlakuan } & \multicolumn{8}{|c|}{ Hipertensi } \\
\cline { 2 - 10 } & \multicolumn{2}{|c|}{ TD Ringan } & \multicolumn{2}{|c|}{$\begin{array}{c}\text { TD } \\
\text { Sedang }\end{array}$} & $\begin{array}{c}\text { TD } \\
\text { Berat }\end{array}$ & Rerata & $\mathrm{n}$ & $\%$ \\
\hline Pree tes & 13 & $\begin{array}{c}40,6 \\
\%\end{array}$ & 10 & $\begin{array}{c}31,2 \\
\%\end{array}$ & 9 & $\begin{array}{c}28,1 \\
\%\end{array}$ & 2,88 & 32 & 100 \\
\hline Post tes & 19 & $\begin{array}{c}59,4 \\
\%\end{array}$ & 11 & $\begin{array}{c}34,4 \\
\%\end{array}$ & 2 & $6,2 \%$ & 2,47 & 32 & 100 \\
\hline Jumlah & 32 & $\begin{array}{c}100 \\
\%\end{array}$ & 21 & $\begin{array}{c}65,6 \\
\%\end{array}$ & 11 & $\begin{array}{c}34,3 \\
\%\end{array}$ & $6 \%$ & 64 & 200 \\
\hline
\end{tabular}

Berdasarkan Tabel 3 Hari Ke-2 sebelum perlakuan menunjukan yang paling banyak yaitu responden yang Hipertensi ringan sebanyak 13 orang $(40,6 \%)$ dan paling sedikit yaitu Hipertensi Berat sebanyak 9 orang $(28,1 \%)$. Setelah perlakuan menunjukan yang paling banyak yaitu responden yang Hipertensi ringan sebanyak 19 orang $(59,4 \%)$ dan paling sedikit yaitu Hipertensi Berat sebanyak 2 orang $(6,2 \%)$. 
Tabel 4. Hasil pre post intervensi pemberia jus tomat Hari Ketiga

\begin{tabular}{|c|c|c|c|c|c|c|c|c|c|}
\hline \multirow[b]{2}{*}{ Perlakuan } & \multicolumn{9}{|c|}{ Hipertensi } \\
\hline & \multicolumn{2}{|c|}{ TD Ringan } & \multicolumn{2}{|c|}{$\begin{array}{c}\text { TD } \\
\text { Sedang }\end{array}$} & \multicolumn{2}{|c|}{$\begin{array}{c}\text { TD } \\
\text { Berat }\end{array}$} & Rerata & $\mathrm{n}$ & $\%$ \\
\hline Pree tes & 20 & $\begin{array}{c}62,5 \\
\%\end{array}$ & 10 & $\begin{array}{c}31,2 \\
\%\end{array}$ & 2 & $\begin{array}{c}6,2 \\
\%\end{array}$ & 2,44 & 32 & \\
\hline Post te & 27 & $\begin{array}{c}84,4 \\
\%\end{array}$ & 5 & $\begin{array}{c}15,6 \\
\%\end{array}$ & & - & 2,16 & 32 & \\
\hline Jum & 47 & $\begin{array}{c}146,9 \\
\%\end{array}$ & 15 & $\begin{array}{c}46,8 \\
\%\end{array}$ & 2 & $\begin{array}{c}6,2 \\
\%\end{array}$ & $4,6 \%$ & 64 & \\
\hline
\end{tabular}

Berdasarkan Tabel 4 Hari Ke-3 sebelum perlakuan menunjukan yang paling banyak yaitu responden yang Hipertensi ringan sebanyak 20 orang $(62,5 \%)$ dan paling sedikit yaitu Hipertensi Berat sebanyak 2 orang $(6,2 \%)$. Setelah perlakuan menunjukan yang paling banyak yaitu responden yang Hipertensi ringan sebanyak 27 orang $(84,4 \%)$ dan sudah tidak ada yang mengalami Hipertensi berat.

Tabel 5. Hasil pre post intervensi pemberia jus tomat Hari Keempat

\begin{tabular}{|c|c|c|c|c|c|c|c|c|c|}
\hline \multirow{2}{*}{ Perlakuan } & \multicolumn{10}{|c|}{ Hipertensi } \\
\cline { 2 - 10 } & \multicolumn{2}{|c|}{ TD Ringan } & \multicolumn{2}{|c|}{$\begin{array}{c}\text { SD } \\
\text { Sedang }\end{array}$} & $\begin{array}{c}\text { TD } \\
\text { Berat }\end{array}$ & Rerata & $\mathrm{n}$ & $\%$ \\
\hline Pree tes & - & - & 29 & $\begin{array}{c}90,6 \\
\%\end{array}$ & 3 & $\begin{array}{c}9,4 \\
\%\end{array}$ & 2,09 & 32 & 100 \\
\hline Post tes & 12 & $\begin{array}{c}37,5 \\
\%\end{array}$ & 20 & $\begin{array}{c}62,5 \\
\%\end{array}$ & - & - & 1,62 & 32 & 100 \\
\hline Jumlah & 12 & $\begin{array}{c}37,5 \\
\%\end{array}$ & 49 & $\begin{array}{c}152,1 \\
\%\end{array}$ & 3 & $\begin{array}{c}9,4 \\
\%\end{array}$ & $\begin{array}{c}3,71 \\
\%\end{array}$ & 64 & 200 \\
\hline
\end{tabular}

Berdasarkan table 5 Hari Ke-4 sebelum perlakuan menunjukan Hipertensi ringan sebanyak 29 orang $(90,6 \%)$ Hipertensi Sedang sebanyak 3 orang $(9,4 \%)$. Setelah perlakuan menunjukan Tekanan darah Normal sebanyak 12 orang $(37,5 \%)$ Hipertensi Ringan sebanyak 20 orang $(62,5 \%)$.

Analisa Statistik Pengaruh Pemberia Jus Tomat Terhadap Perubahan Tekanan Darah Pada Usia 35-45 Tahun

Tabel 6. Analisa berdasarkan Uji Wilcoxon Pengaruh pre dan post Perlakuan Hari Pertama

\begin{tabular}{|c|c|c|c|c|c|c|c|c|}
\hline \multirow{3}{*}{$\begin{array}{l}\text { Perlakuan } \\
\text { Pree tes }\end{array}$} & \multicolumn{8}{|c|}{ Hipertensi } \\
\hline & \multicolumn{2}{|c|}{ TD Ringan } & \multicolumn{2}{|c|}{$\begin{array}{c}\text { TD } \\
\text { Sedang } \\
\end{array}$} & \multicolumn{2}{|c|}{$\begin{array}{c}\text { TD } \\
\text { Berat }\end{array}$} & \multirow[t]{2}{*}{$\mathrm{n}$} & \\
\hline & 11 & $\begin{array}{c}34,4 \\
\%\end{array}$ & 7 & $\begin{array}{c}21,9 \\
\%\end{array}$ & 14 & $\begin{array}{c}43,8 \\
\%\end{array}$ & & \\
\hline $\mathrm{Po}$ & 12 & $\begin{array}{c}37,5 \\
\%\end{array}$ & 11 & $\begin{array}{c}34,4 \\
\%\end{array}$ & 9 & 28,1 & 32 & 10 \\
\hline & 23 & $\begin{array}{c}71,9 \\
\%\end{array}$ & 18 & $\begin{array}{c}56,3 \\
\%\end{array}$ & 23 & $\begin{array}{c}71,9 \\
\%\end{array}$ & 64 & 20 \\
\hline
\end{tabular}

Nilai $(\rho)=0,014$

Tabel 3.6 menunjukkan tekanan darah Hari Ke-1 Sebelum perlakuan menunjukan yang paling banyak yaitu responden yang Hipertensi Berat sebanyak 14 orang $(43,8)$ dan paling sedikit yaitu Hipertensi
Sedang sebanyak 7 orang (21,9\%). Setelah perlakuan menunjukan yang paling banyak yaitu responden yang Hipertensi ringan sebanyak 12 orang $(37,5 \%)$ dan paling sedikit yaitu Hipertensi Berat sebanyak 9 orang (28.1\%). Hasil uji wilcoxon menunjukan ada pengaruh pemberian jus tomat terhadap perubahan tekanan darah dengan nilai $(\rho) 0,014$ karena nilai $(\rho)$ lebih kecil dari nilai (a) 0,05 maka $\mathrm{H} 0$ ditolak dan $\mathrm{Ha}$ diterima artinya perbrdaan yang signifikan antara tekanan darah sebelum dan sesudah pemberian jus tomat.

Tabel 7. Analisa berdasarkan Uji Wilcoxon Pengaruh pre dan post Perlakuan Hari Kedua

\begin{tabular}{|c|c|c|c|c|c|c|c|c|}
\hline \multirow{2}{*}{ Perlakuan } & \multicolumn{8}{|c|}{ Hipertensi } \\
\cline { 2 - 9 } & \multicolumn{2}{|c|}{ TD Ringan } & $\begin{array}{c}\text { TD } \\
\text { Sedang }\end{array}$ & \multicolumn{2}{|c|}{ TD Berat } & $\mathrm{n}$ & $\%$ \\
\hline Pree tes & 13 & $\begin{array}{c}40,6 \\
\%\end{array}$ & 10 & $\begin{array}{c}31,2 \\
\%\end{array}$ & 9 & $\begin{array}{c}28,1 \\
\%\end{array}$ & 32 & 100 \\
\hline Post tes & 19 & $\begin{array}{c}59,4 \\
\%\end{array}$ & 11 & $\begin{array}{c}34,4 \\
\%\end{array}$ & 2 & $\begin{array}{c}6,2 \\
\%\end{array}$ & 32 & 100 \\
\hline Jumlah & 32 & $\begin{array}{c}100 \\
\%\end{array}$ & 21 & $\begin{array}{c}65,6 \\
\%\end{array}$ & 11 & $\begin{array}{c}34,3 \\
\%\end{array}$ & 64 & 200 \\
\hline
\end{tabular}

Nilai $(\rho)=0,00$

Tabel 7 menunjukkan tekanan darah Hari Ke-2 sebelum perlakuan menunjukan yang paling banyak yaitu responden yang Hipertensi ringan sebanyak 13 orang $(40,6 \%)$ dan paling sedikit yaitu Hipertensi Berat sebanyak 9 orang $(28,1 \%)$. Setelah perlakuan menunjukan yang paling banyak yaitu responden yang Hipertensi ringan sebanyak 19 orang $(59,4 \%)$ dan paling sedikit yaitu Hipertensi Berat sebanyak 2 orang $(6,2 \%)$. Hasil uji wilcoxon menunjukan ada pengaruh pemberian jus tomat terhadap perubahan tekanan darah dengan nilai $(\rho)$ 0,000 karena nilai $(\rho)$ lebih kecil dari nilai (a) 0,05 maka $\mathrm{H} 0$ ditolak dan $\mathrm{Ha}$ diterima artinya perbrdaan yang signifikan antara tekanan darah sebelum dan sesudah pemberian jus tomat.

Tabel 8. Analisa berdasarkan Uji Wilcoxon Pengaruh pre dan post Perlakuan Hari Ketiga

\begin{tabular}{|c|c|c|c|c|c|c|c|c|}
\hline \multirow{2}{*}{ Perlakuan } & \multicolumn{8}{|c|}{ Hipertensi } \\
\cline { 2 - 9 } & TD Ringan & \multicolumn{2}{|c|}{ TD Sedang } & \multicolumn{2}{|c|}{$\begin{array}{c}\text { TD } \\
\text { Berat }\end{array}$} & $\mathrm{n}$ & $\%$ \\
\hline Pree tes & 20 & $\begin{array}{c}62,5 \\
\%\end{array}$ & 10 & $\begin{array}{c}31,2 \\
\%\end{array}$ & 2 & $\begin{array}{c}6,2 \\
\%\end{array}$ & 32 & 100 \\
\hline Post tes & 27 & $\begin{array}{c}84,4 \\
\%\end{array}$ & 5 & $\begin{array}{c}15,6 \\
\%\end{array}$ & - & - & 32 & 100 \\
\hline Jumlah & 47 & $\begin{array}{c}146,9 \\
\%\end{array}$ & 15 & $\begin{array}{c}46,8 \\
\%\end{array}$ & 2 & $\begin{array}{c}6,2 \\
\%\end{array}$ & 64 & 200 \\
\hline
\end{tabular}

Nilai $(\rho)=0,003$

Tabel 8 menunjukkan tekanan darah Ke-3 sebelum perlakuan menunjukan yang paling banyak yaitu responden yang Hipertensi ringan sebanyak 20 orang $(62,5 \%)$ dan paling sedikit yaitu Hipertensi Berat sebanyak 2 orang $(6,2 \%)$. Setelah perlakuan menunjukan yang paling banyak yaitu responden yang 
Hipertensi ringan sebanyak 27 orang $(84,4 \%)$ dan sudah tidak ada yang mengalami Hipertensi berat. Hasil uji wilcoxon menunjukan ada pengaruh pemberian jus tomat terhadap perubahan tekanan darah dengan nilai $(\rho)$ 0,003 karena nilai $(\rho)$ lebih kecil dari nilai (a) 0,05 maka $\mathrm{H} 0$ ditolak dan $\mathrm{Ha}$ diterima artinya perbrdaan yang signifikan antara tekanan darah sebelum dan sesudah pemberian jus tomat.

Tabel 9. Analisa berdasarkan Uji Wilcoxon Pengaruh pre dan post Perlakuan Hari Keempat

\begin{tabular}{|c|c|c|c|c|c|c|c|c|}
\hline \multirow{2}{*}{ Perlakuan } & \multicolumn{8}{|c|}{ Hipertensi } \\
\cline { 2 - 9 } & \multicolumn{2}{|c|}{ TD Ringan } & \multicolumn{2}{|c|}{ TD Sedang } & \multicolumn{2}{|c|}{$\begin{array}{c}\text { TD } \\
\text { Berat }\end{array}$} & $\mathrm{n}$ & $\%$ \\
\hline Pree tes & - & - & 29 & $\begin{array}{c}90,6 \\
\%\end{array}$ & 3 & $\begin{array}{c}9,4 \\
\%\end{array}$ & 3 & 100 \\
\hline Post tes & 12 & $\begin{array}{c}37,5 \\
\%\end{array}$ & 20 & $\begin{array}{c}62,5 \\
\%\end{array}$ & - & - & 3 & 100 \\
\hline Jumlah & 12 & $\begin{array}{c}37,5 \\
\%\end{array}$ & 49 & $\begin{array}{c}153,1 \\
\%\end{array}$ & 3 & $\begin{array}{c}9,4 \\
\%\end{array}$ & 6 & 200 \\
\hline
\end{tabular}

Nilai $(\rho)=0,000$

Tabel 9 menunjukkan tekanan darah Hari Ke-4 sebelum perlakuan menunjukan Hipertensi ringan sebanyak 29 orang $(90,6 \%)$ Hipertensi Sedang sebanyak 3 orang $(9,4 \%)$. Setelah perlakuan menunjukan Tekanan darah Normal sebanyak 12 orang $(37,5 \%)$ Hipertensi Ringan sebanyak 20 orang $(62,5 \%)$. Hasil uji wilcoxon menunjukan ada pengaruh pemberian jus tomat terhadap perubahan tekanan darah dengan nilai $(\rho) 0,000$ karena nilai $(\rho)$ lebih kecil dari nilai (a) 0,05 maka $\mathrm{H} 0$ ditolak dan Ha diterima artinya perbrdaan yang signifikan antara tekanan darah sebelum dan sesudah pemberian jus tomat.

\section{Pembahasan}

\section{Tekanan Darah Sebelum dan Sesudah Diberikan Terapi Jus Tomat Pada Penderita Hipertensi}

Hasil penelitian terhadap 32 responden sebelum dan sesudah dilakukan terapi jus tomat didapatkan pada hari ke-1 terdapat 21 responden yang mengalami perubahan tekanan darah dan 11 responden tidak mengalami perubahan tekan darah. Pada hari ke-2 sebelum dan sesudah dilakukan terapi jus tomat didapatkan 26 responden mengalami perubahan tekanan darah dan 6 responden tidak mengalami perubahan tekanan darah. Pada hari ke-3 sebelum dan sesudah dilakukan terapi jus tomat didapatkan 32 responden mengalami perubahan tekanan darah begitupun dihari ke-4 seluruh responden mengalami perubahan tekanan darah. Kesimpulan dari statistik ini adalah ada perubahan yang signifikan antara pemberian jus tomat terhadap perubahan tekanan darah pada penderita hipertensi dengan nilai $\rho<0,05$.

Tekanan darah responden berbeda-beda satu sama lain tergantung factor-faktor yang mempengaruhinya baik itu dari internal maupun eksternal [3].
Efek terapi jus tomat menurunkan tekanan darah karena tomat kaya akan kalium, sedikit natrium, dan lemak. Kerja kalium yaitu, kalium menghambat pelepasan renin sehingga mengubah sistem renin angiotensin. Bioflavonoid yang terapat dalam tomat mengurangi bahaya kolesterol dan mencegah penggumpalan darah. Bioflavonoid mudah larut dalam air sehingga dapat melancarkan keluarnya air seni sehingga menyebabkan anti hipertensi. Hal ini sangat berhubungan dengan ACE sehingga angiotensin I tidak dapat diubah menjadi angiotensi II. Akibatnya jumlah angiotensin II berkurang dan menyebabkan vasokonstriksi dan sekresi aldosteron untuk reabsorbsi natrium dan air secara otomatis akan menjadi berkurang sehingga tekanan darah menjadi turun. Selain kalium tomat juga mengandung likopain yang berperan sebagai antioksidan yang menghambat penyerapan oksigen reaktif terhadap endotel yang dapat menganggu dalatasi pembuluh darah yang menyebabkan hipertensi sehingga tomat dapat berperan dalam menurunkan tekanan darah [4]. Kalium dalam jus tomat menurunkan tekanan darah sistolik dan diastolik dengan menghambat pelepasan renin sehingga terjadi peningkatan ekskresi natrium dan air. Diet rendah kalium dapat menyebabkan hipertensi serta memicu terjadinya defisiensi kalium dalam tubuh sebagai akibat dari kurangnya simpanan kalium dalam ginjal dan hilangnya kalium melalui feses dan urin. Selain itu, kalium juga mempertahankan fungsi sel pembuluh endotel melalui peningkatan produksi NO yang berpengaruh terhadap penurunan tekanan darah sistolik maupun diastolik dengan cara vasodilatasi atau relaksasi otot halus pembuluh darah. Terdapat 4,6 mg likopen dalam 100 gram tomat segar. Likopen menurunkan tekanan darah melalui perannya sebagai antioksidan. Likopen mencegah radikal bebas menimbulkan stress oksidatif, kemudian memicu produksi nitrit oksida pada endothelium dan meningkatkan fungsi vaskuler sehingga terjadi penurunan tekanan darah [5].

Hasil penelitian ini di dukung penelitian dari penelitian Wahyuni, Ferti Estri Suryanni, 2017 di desa Monggot Kecamatan Geyer Kabupaten Grobogan sample yang digunakan adalah 20 orang penderita hipertensi stange 1 yang diberi intervensi pemberian jus tomat selama 7 hari, didapatkan hasil sistole $147,10 \mathrm{mmHg}$ dan diastole $87,20 \mathrm{mmHg}$. Rata rata tekanan darah setelah dilakukan intervensi pemberian jus tomat tekanan darah sistole menjadi $140,50 \mathrm{mmHg}$ dan tekanan darah diastole 87,20 $\mathrm{mmHg}$, hasil analisis menunjukkan $\rho: 0,011(\rho<0.05)$ hal tersebut menunjukkan terdapat pengaruh penurunan tekanan darah penderita hipertensi stange 1 setelah diberikan terapi jus tomat. Penelitian lain juga didukung oleh penelitian dari Sukma Paramita R \& Niken Puruhita (2015) yang berjudul "Pengaruh Pemberian Jus Tomat (Lycopersicum Commune) Terhadap Tekanan Darah Sistole Dan Diastole Laki- 
Laki Hipertensif Usian 40-45" Hasil penelitiannya yaitu Pemberian $200 \mathrm{ml}$ jus tomat (lycopersicum commune dapat membantu menurunkan tekanan darah sistolik dan diastolik pada laki-laki usia 40-45 tahun.

\section{KESIMPULAN}

Berdasarkan dari hasil penelitian yang telah dilakukan serta diuraikan pada pembahasan yang terpapar di bab sebelumnya di dapatkan hasil analisa jus tomat diperoleh nilai sig $\rho \mathrm{V}$ hari Pertama $=0,014<\alpha 0,05$, artinya ada pengaruh pemberia terapi jus tomat terhadap perubahan tekanan darah pada penderita hipertensi. Hasil analisa jus tomat diperoleh nilai sig $\rho \mathrm{V}$ hari Kedua $=$ $0,000<\alpha 0,05$, artinya ada pengaruh pemberia terapi jus tomat terhadap perubahan tekanan darah pada penderita hipertensi. Hasil analisa jus tomat diperoleh nilai sig $\rho \mathrm{V}$ hari Ketiga $=0,003<\alpha \quad 0,05$, artinya ada pengaruh pemberia terapi jus tomat terhadap perubahan tekanan darah pada penderita hipertensi. Dan hasil analisa jus tomat diperoleh nilai sig $\rho \mathrm{V}$ hari Keempat $=0,000<\alpha$ 0,05 , artinya ada pengaruh pemberia terapi jus tomat terhadap perubahan tekanan darah pada penderita hipertensi, maka peneliti dapat memberikan kesimpulan yaitu ada perubahan yang signifikan antara tekanan darah sebelum dan sesudah pemberian jus tomat pada penderita hipertensi pada usia 35-45 tahun di Desa Kempo Kecematan Kempo Kabupaten Dompu tahun 2019.

\section{DAFTAR PUSTAKA}

[1] Hengli Dkk. 2013. Keperawatan Medikal Bedah. Yogyakarta : Pustaka Pelajar

[2] Sugiyono. 2014. Statistika Untuk Penelitian. Bandung: Alfabeta

[3] Ella Thalia. 2015. Efektivitas Pemberian Terapi Jus Tomat Dan Tomat Rebus Terhadap Perubahan Tekanan Darah Pada Penderita Hipertensi Di Desa Temenggungan Kec. Karas Kab. Magetan

[4] Raharjo. 2017. Pengaruh Konsumsi Jus Tomat Dengan Perubahan Tekanan Darah Sistolik Dan Diastolik.

[5] Noviyanti Choirunnisa Hasibuan, M. Ricky Ramadhian. 2016. "Efektivitas Kandungan Kalium dan Likopen yang Terdapat Dalam Tomat (Solanum lycipersicum) Terhadap Penurunan Tekanan Darah Tinggi”. Universitas Lampung; Lampung 